\title{
Deteksi Mycobacterium tuberculosis pada Sampel Sputum menggunakan Teknik Loop-Mediated Isothermal Amplification (LAMP-TB)
}

\author{
${ }^{1}$ Rama L. Sumual \\ ${ }^{2}$ Greta J. P. Wahongan \\ ${ }^{2}$ Josef S. B. Tuda
}

${ }^{1}$ Program Studi Pendidikan Dokter Fakultas Kedokteran Universitas Sam Ratulangi Manado ${ }^{2}$ Staf Pengajar bagian Parasitologi Fakultas Kedokteran Universitas Sam Ratulangi

Email: jsbtuda@yahoo.com

\begin{abstract}
Pulmonary TB is still a threat included in top 10 causes of death in the world. Limitation in diagnostic methods is one of the obstacles in improving the detection of pulmonary TB cases. WHO recommend Loop-Mediated Isothermal Amplification (TBLAMP) with sensitivity, specificity, high efficiency, fast, and simple in terms of molecular method to identify Mycobacterium tuberculosis. This study was aimed to find out whether LAMP-TB could detect $M$. tuberculosis in the sputum samples. This was a descriptive observational/survey study using a diagnostic test with a cross-sectional design. Samples were patients suspected as pulmonary TB with negative result in sputum smear microscopy at Prof. Dr. R. D. Kandou Hospital Manado during September until October 2017. The results obtained 25 samples of patients suspected pulmonary TB with negative result in sputum smear microscopy. Most of them were at the age of 52-64 years, male (18 people; $72 \%$ ), and had purulent sputum (14 samples; 56\%). Examination by using LAMP-TB obtained 4 samples (16\%) stated as positive M. tuberculosis and 21 samples (84\%) stated as negative $M$. tuberculosis. Conclusion: TB-LAMP could detect Mycobacterium tuberculosis in the sputum samples.
\end{abstract}

Keywords: pulmonary TB, M.tuberculosis, TB-LAMP

\begin{abstract}
Abstrak: TB Paru saat ini masih menjadi ancaman dan termasuk 10 besar penyebab kematian teratas di dunia. Keterbatasan metode diagnostik merupakan salah satu hambatan dalam meningkatkan temuan kasus TB Paru. Saat ini WHO telah merekomendasikan metode LoopMediated Isothermal Amplification (LAMP-TB) yang memiliki sensitivitas, spesifitas, efisiensi tinggi, cepat dan sederhana dalam hal metode molekular untuk mengidentifikasi Mycobacterium tuberculosis. Penelitian ini bertujuan untuk mengetahui apakah teknik LAMPTB dapat mendeteksi M.tuberculosis pada sampel sputum. Jenis penelitian ialah deskriptif observasional/survei dengan pendekatan uji diagnostik secara potong lintang pada pasien terduga TB Paru BTA negatif di RSUP Prof. Dr. R. D. Kandou Manado selama bulan September-Oktober 2017. Dari 25 sampel pasien terduga TB paru BTA negatif didapatkan sebagian besar berusia 52-64 tahun, berjenis kelamin laki-laki 18 orang (72\%), dan konsistensi sputum purulen pada 14 sampel (56\%). Pemeriksaan dengan menggunakan metode LAMP-TB mendapatkan 4 sampel (16\%) dinyatakan positif mengandung M.tuberculosis dan 21 sampel (84\%) dinyatakan negatif. Simpulan: Metode LAMP-TB dapat mendeteksi M.Tuberculosis dalam sampel sputum.
\end{abstract}

Kata kunci: TB paru, M.tuberculosis, LAMP-TB

Penyakit tuberkulosis paru (TB paru) merupakan suatu penyakit infeksi kronik yang sudah sangat lama dikenal sejak 2000-4000 SM. ${ }^{1}$ WHO menyatakan bahwa 
TB paru sampai saat ini masih menjadi ancaman dan perhatian dunia. Saat ini TB termasuk 10 penyebab kematian teratas di dunia tahun 2015 dan di estimasi sekitar 10,4 juta kasus baru TB di dunia. Terdapat 6 negara yang menempati sekitar $60 \%$ kasus baru di dunia yaitu: India, Indonesia, China, Nigeria, Pakistan, dan Afrika Selatan. Secara global, angka kematian TB sekitar $22 \%$ dari total kematian dunia dari tahun 2000 sampai 2015. Pada tahun 2015, 1,8 juta orang meninggal akibat terinfeksi TB. Di Asia Tenggara angka kejadian baru tahun 2015 ialah 4.7 juta kasus sedangkan angka kematiannya 74 ribu kasus. ${ }^{1,2} \mathrm{Di}$ Indonesia tahun 2016 dilaporkan terdapat 156.723 kasus TB. ${ }^{3}$ Pada tahun 2015 total kasus yang dilaporkan 333.119 dengan $64 \%$ didiagnosis dengan pemeriksaan bakteriologi. $^{2}$ Berdasarkan karakteristik penduduk, prevalensi TB paru cenderung meningkat dengan bertambahnya usia, pendidikan rendah, dan tidak bekerja. ${ }^{4}$

Meningkatnya angka kematian sebenarnya dapat dicegah sehubungan dengan telah ditemukannya kuman penyebab TB sehingga dapat diterapi. Terapi TB sampai saat ini telah menyelamatkan 49 juta orang di dunia. Pada tahun 2014 angka kesuksesan terapi TB untuk orang yang baru terdiagnosis TB ialah 83\%. Kematian umumnya disebabkan karena tidak terdeteksinya kuman TB atau akibat kegagalan dalam pengobatan. Salah satu masalah dalam penanggulangan TB yaitu sulitnya mendeteksi penderita TB paru basil tahan asam (BTA) positif. ${ }^{2}$

Keterbatasannya dari teknik atau metode diagnostik saat ini merupakan salah satu hambatan dalam meningkatkan penemuan kasus TB paru. Metode diagnostik yang sering digunakan dan sudah menjadi gold standard ialah pemeriksaan BTA dengan pewarnaan Ziehl Neelsen. ${ }^{1}$

Terdapat kelemahan dalam hal teknik pembuatan sediaan dan interpretasi hasil dari pemeriksaan BTA. ${ }^{5}$ Jumlah bakteri yang dibutuhkan relatif besar, yaitu minimal $10^{4}-10^{5}$ bakteri/ml sputum untuk mendapatkan hasil positif sehingga umumnya hanya efektif terhadap pasien yang sudah memiliki manifestasi klinis. ${ }^{6,7}$ Manisfestasi klinis TB perlu waktu hampir satu bulan atau bahkan lebih sebelum dapat menimbulkan respon imunitas selular dan jumlah bakteri dapat ditemukan dalam jumlah cukup banyak di dalam sputum., ${ }^{8,9}$

Prevalensi TB-HIV meningkat pada dekade terakhir juga menambah kesulitan pembacaan mikroskopik BTA. Hasil negatif palsu sering muncul akibat menurunnya kemampuan makrofag menangkap bakteri sehingga jumlah bakteri yang kemudian dapat berkembangbiak serta ditemukan di dalam sputum menjadi sangat sedikit. $^{10}$

Selain pemeriksaan BTA terdapat juga pemeriksaan dengan teknik biakan (kultur). Kelemahan tehnik ini ialah pertumbuhan koloni yang lamanya 4-6 minggu menyebabkan deteksi cepat (rapid test) tidak bisa dilakukan. ${ }^{1}$ Pemeriksaan Polymerase Chain Reaction (PCR) yang lebih spesifik dalam mendeteksi DNA kuman TB tapi selain mahal karena penggunaan peralatan yang khusus yaitu termocycler dll juga memerlukan suhu reaksi agar proses amplifikasi dapat terjadi; juga sering terjadi kegagalan amplifikasi DNA saat proses reaksi berlangsung serta deteksi hasil amplifikasi yang rumit dengan metode elektroforesis untuk mendeteksi jumlah produk DNA yang teramplifikasi. ${ }^{5,11}$ Terdapat juga pemeriksaan Genxpert dengan pemeriksaan Xpert MTB/RIF. Metode ini merupakan uji cepat (rapid test) untuk diagnosis penyakit TB tetapi sampai saat ini metode ini di Indonesia hanya dipakai untuk pasien TB gagal pengobatan, TB relaps maupun TBHIV dan memiliki sistem operasional yang tergolong rumit. $^{12}$

Loop-Mediated Isothermal Amplification (LAMP) merupakan suatu metode uji diagnostik molekular yang diperkenalkan di Jepang sejak tahun 1999 untuk mendeteksi penyakit infeksius seperti $\mathrm{TB} .^{13-15}$ Selain memiliki sensitivitas, spesifitas dan efisiensi tinggi, metode LAMP-TB juga cepat dan sederhana dalam hal teknik molekular untuk mengidentifikasi beberapa penyakit, salah satunya ialah TB. ${ }^{16-18}$ Metode LAMP menggunakan amplifikasi 
DNA pada suhu tetap, sehingga penggunaan alat thermocycler yang mahal tidak diperlukan. Kegagalan proses amplifikasi pada metode LAMP dapat diatasi dengan menambahkan enzim yang dapat menjadi substrat selama proses reaksi amplifikasi berlangsung. Sistem deteksi pada teknik ini juga sederhana karena produk DNA yang akan dideteksi dapat berupa endapan atau perubahan warna/fluoresensi. Interpretasi hasil dapat dilakukan secara sederhana yaitu dengan menggunakan mata telanjang atau sinar UV sederhana. ${ }^{5,13,19}$

Menurut WHO metode LAMP-TB memiliki sensitivitas $15 \%$ lebih tinggi daripada pemeriksaan BTA $(78 \%$ dengan $63 \%) .{ }^{17}$ Penelitian terakhir menemukan bahwa spesifitas dan sensitivitas metode LAMP lebih tinggi dari pada pemeriksaan Ziehl Neelsen khususnya yang telah dinyatakan negatif, ${ }^{18,20}$ dan mendapatkan hasil positif untuk 16 sampel yang dinyatakan negatif pada pewarnaan Ziehl Neelsen. ${ }^{18}$

Penelitian ini bertujuan untuk melakukan deteksi DNA Mycobacterium tuberculosis dengan menggunakan metode LAMP-TB pada sampel yang telah dinyatakan negatif saat pemeriksaan BTA dengan pewarnaan Ziehl Neelsen.

\section{METODE PENELITIAN}

Jenis penelitian ini ialah deskriptif observasional/survei dengan pendekatan uji diagnostik dan desain potong lintang untuk mendeteksi DNA $M$. tuberculosis menggunakan teknik LAMP-TB terhadap sampel sputum yang telah dinyatakan negatif dengan pewarnaan Ziehl Neelsen.

Penelitian ini dilaksanakan pada bulan September s/d Oktober 2017. Pengambilan sampel dilakukan di RSUP Prof. Dr. R. D. Kandou Manado dan pemeriksaan LAMPTB dilakukan di Laboratorium Biomolekuler Bagian Parasitologi Klinik Fakultas Kedokteran Unsrat Manado.

Dalam penelitian ini terdapat 25 sampel pasien yang mempunyai gejala klinis TB dan telah dinyatakan tidak ditemukan BTA pada pewarnaan Ziehl Neelsen.
Alat dan bahan yang digunakan yaitu sampel sputum, kontrol positif, kontrol negatif, reagen ekstraksi, reagen amplifikasi, waterbath, inkubator, micro-tube, lampu fluoresens/sinar UV. Selanjutnya pada sampel sputum dilakukan pemeriksaan LAMP-TB.

Analisis data yang digunakan ialah analisis statistik deskriptif jenis univariat. Penyajian datanya dalam bentuk tabel, frekuensi, mean, modus, dan sebagainya yang menggunakan aplikasi SPSS dan Microsoft Excel.

\section{HASIL PENELITIAN \\ Karakteristik subjek penelitian}

Pengambilan sampel dilakukan di RSUP Dr. R. D. Kandou Manado dan diteliti di Laboratorium Biomolekuler Bagian Parasitologi Klinik Fakultas Kedokteran Universitas Sam Ratulangi dengan pendekatan uji diagnostik pada 25 orang terduga (suspect) TB paru yang memenuhi kriteria inklusi dan eksklusi dengan kisaran usia 13-86 tahun. Jumlah sampel yang diambil sebanyak 25 sampel atau dengan kata lain satu sampel perorang. Sampel penelitian diambil dari para pasien yang diduga mengidap TB paru yang memiliki gejala batuk produktif $>2$ minggu, batuk darah, dll.

Tabel 1 memperlihatkan usia rerata pasien terduga TB paru BTA negatif ialah 54 tahun dengan usia termuda 13 tahun dan usia tertua 86 tahun. Kelompok usia terbanyak ialah usia 52-64 tahun.

Tabel 1. Distribusi pasien terduga TB paru BTA negatif menurut usia

\begin{tabular}{ccc}
\hline $\begin{array}{c}\text { Usia } \\
\text { (tahun) }\end{array}$ & $\begin{array}{c}\text { Jumlah } \\
(\mathbf{n})\end{array}$ & $\begin{array}{c}\text { Persentase } \\
(\boldsymbol{\%})\end{array}$ \\
\hline $13-25$ & 2 & 8 \\
$26-38$ & 5 & 20 \\
$39-51$ & 3 & 12 \\
$52-64$ & 8 & 32 \\
$65-77$ & 3 & 12 \\
$78-80$ & 2 & 8 \\
$>80$ & 2 & 8 \\
Total & 25 & 100 \\
\hline
\end{tabular}


Tabel 2 memperlihatkan bahwa distribusi pasien terduga TB paru BTA negatif menurut jenis kelamin terbanyak ialah jenis kelamin laki-laki 18 pasien (72\%) dibandingkan jenis kelamin perempuan 7 pasien $(28 \%)$.

Tabel 2. Distribusi pasien terduga TB paru BTA negatif menurut jenis kelamin

\begin{tabular}{ccc}
\hline Jenis kelamin & $\begin{array}{c}\text { Jumlah } \\
(\mathbf{n})\end{array}$ & $\begin{array}{c}\text { Persentase } \\
(\boldsymbol{\%})\end{array}$ \\
\hline Laki-laki & 18 & 72 \\
Perempuan & 7 & 28 \\
Total & 25 & 100 \\
\hline
\end{tabular}

Tabel 3 memperlihatkan bahwa pasien terduga TB paru BTA negatif menurut konsistensi sputum didapatkan terbanyak ialah konsistensi purulen pada 14 pasien (56\%) dan yang paling sedikit konsistensi mukopurulen pada 1 pasien (4\%).

Tabel 3. Distribusi pasien terduga TB paru BTA negatif menurut konsistensi sputum

\begin{tabular}{lcc}
\hline $\begin{array}{c}\text { Konsistensi } \\
\text { sputum }\end{array}$ & $\begin{array}{c}\text { Jumlah } \\
(\mathbf{n})\end{array}$ & $\begin{array}{c}\text { Persentase } \\
(\boldsymbol{\%})\end{array}$ \\
\hline Mukous & 7 & 28 \\
Mukopurulen & 1 & 4 \\
Purulen & 14 & 56 \\
Bloody purulent & 3 & 12 \\
Total & 25 & 100 \\
\hline
\end{tabular}

\section{Hasil pemeriksaan LAMP-TB}

Pada Tabel 4 di atas terlihat bahwa hasil penelitian dari 25 sampel pasien terduga TB Paru BTA negatif didapatkan yang terbanyak adalah hasil negatif 21 $(84 \%)$ dan yang paling sedikit hasil positif $4(16 \%)$.

Tabel 4 Hasil pemeriksaan (metode LAMPTB)

\begin{tabular}{ccc}
\hline Hasil & $\begin{array}{c}\text { Jumlah } \\
(\mathbf{n})\end{array}$ & $\begin{array}{c}\text { Persentase } \\
(\boldsymbol{\%})\end{array}$ \\
\hline Positif & 4 & 16 \\
Negatif & 21 & 84 \\
Total & 25 & 100 \\
\hline
\end{tabular}

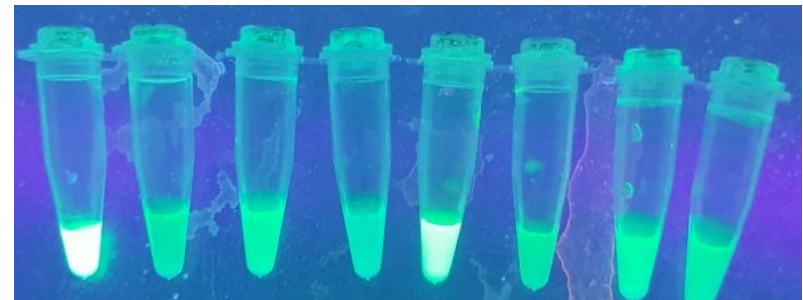

Gambar 1. Hasil pemeriksaan LAMP-TB menggunakan sinar fluoresens

\section{BAHASAN \\ Karakteristik subjek penelitian}

Penelitian ini dilakukan terhadap 25 orang pasien TB paru BTA negatif. Sebagian besar berada pada kisaran usia 52-64 tahun yaitu 8 orang (32\%) dengan usia termuda 13 tahun dan tertua 86 tahun (rerata 54 tahun). Hasil penelitian ini selaras dengan penelitian yang dilakukan Putra $^{21}$ di RSUD Dr. Moewardi, Surakarta, yang mendapatkan kelompok usia terbanyak ialah 46-55 tahun $(21,6 \%)$ dan 56-65 tahun. Hasil yang berbeda didapatkan oleh Kurniawan $^{22}$ di RSUP dr. M Djamil Padang yang melaporkan kelompok usia terbanyak ialah 20-29 tahun yaitu 11 orang $(27,5 \%)$. Setiarsih $^{23}$ di Rumah Sakit Persahabatan Jakarta mendapatkan kelompok usia terbanyak ialah 17-25 tahun yaitu 13 orang $(39,39 \%)$.

Di daerah dengan tingkat pertumbuhan penduduk yang tinggi yang umumnya daerah miskin, urbanisasi yang cepat, tidak adanya atau tidak efektifnya program penanggulangan TB dan infeksi HIV, insidens penyakit TB cenderung meningkat pada usia muda dan usia dewasa aktif. Di daerah dengan pertumbuhan penduduk yang rendah, kelompok usia yang paling sering terkena penyakit TB ialah orang dewasa di atas 55 tahun yang mungkin disebabkan menurunnya kekebalan tubuh. ${ }^{24}$

Pada penelitian ini didapatkan insidens penyakit TB cenderung lebih banyak pada usia lebih tua kisaran usia 52-64 tahun. Pasien dalam penelitian ini, yaitu TB paru dengan BTA negatif, sering dikaitkan dengan kekebalan tubuh yang menurun oleh karena faktor penuaan dalam hal ini respon imun tubuh terhadap penyakit, penggunaan obat imunosupresan (TNF- $\alpha$ 
antagonists, kortikosteroid, dll), kanker, dan individu dengan HIV positif. ${ }^{1,25}$

Berdasarkan jenis kelamin, pada distribusi penyakit TB paru BTA negatif didapatkan pasien laki-laki 18 orang $(71,6 \%)$ dan pasien perempuan 7 orang $(28,4 \%)$. Hasil ini sesuai dengan penelitian oleh Kurniawan ${ }^{22}$ di RSUP dr. M Djamil Padang yang mendapatkan laki-laki 24 orang $(60 \%)$ dan perempuan 16 orang (40\%). Setiarsih ${ }^{23}$ di Rumah Sakit Persahabatan Jakarta mendapatkan laki-laki 20 orang $(60,60 \%)$ dan perempuan 13 orang $(39,39 \%)$. Demikian pula, Putra ${ }^{21}$ di RSUD Dr. Moewardi Surakarta mendapatkan lakilaki $71,6 \%$ dan perempuan $28,4 \%$. Andina $^{26}$ di RS Haji Adam Malik, RSU Pirngadi dan Balai Pengobatan Penyakit Paru Medan mendapatkan laki-laki 25 orang $(69,5 \%)$ dan perempuan 11 orang $(30,5 \%)$

Berdasarkan data dari WHO tahun 2016 untuk Afrika, Eropa, Amerika, Asia Tenggara dan terlebih khusus Indonesia diketahui bahwa insidens penyakit TB pada usia >14 tahun didominasi oleh laki-laki, sedangkan $<14$ tahun di Asia Tenggara jenis kelamin perempuan yang lebih dominan daripada jenis kelamin laki-laki. Tingginya angka pasien TB pada laki-laki diduga berhubungan dengan tingkat aktivitas dan pekerjaan yang memungkinkan risiko terkena penyakit $\mathrm{TB} .^{2}$

\section{Hasil pemeriksaan LAMP-TB}

Metode LAMP adalah metode uji diagnostik molekuler cara langsung berdasarkan uji identifikasi asam nukleat bakteri dan merupakan metode modifikasi amplifikasi PCR pada suhu tetap dengan menggunakan 4-6 pasang primer dari gen yang dapat mengidentifikasi sekuens DNA bakteri. Metode LAMP-TB relatif tidak sensitif terhadap akumulasi DNA dan produk sampingan DNA (garam pirofosfat), sehingga reaksi berlangsung sampai sejumlah besar produk DNA (amplikon) dihasilkan. Fitur ini membuat deteksi yang terlihat dari amplifikasi yang berhasil dilakukan dengan menggunakan $d s D N A$ binding dyes seperti SYBR green, dengan mendeteksi kekeruhan yang disebabkan oleh pengendapan magnesium pirofosfat, atau dengan menggunakan pereaksi fluoresensi non-inhibitor. Hasilnya dapat dilihat secara visual dibawah sinar ultraviolet atau lampu fluoresens dengan menggunakan mata telanjang dan metode ini hanya berlangsung $<2$ jam. ${ }^{5,19}$

Pada hasil penelitian dari 25 sampel pasien terduga TB paru BTA negatif didapatkan 4 sampel (16\%) dinyatakan positif terdeteksi bakteri $M$. tuberculosis menggunakan metode LAMP-TB dan sisanya 21 sampel (84\%) dinyatakan negatif mengandung bakteri $M$. tuberculosis. Hasil ini sejalan dengan penelitian yang didapatkan oleh Mitarai $^{27}$ yaitu dari 132 sampel BTA negatif, 33 sampel (25\%) positif LAMP-TB dan 99 sampel (75\%) negatif LAMP-TB. Hasil yang berbeda didapatkan oleh Gray $^{28}$ yaitu dari 142 sampel BTA negatif, 88 sampel $(61,97 \%)$ positif LAMP-TB dan 54 sampel $(38,03 \%)$ negatif LAMP-TB.

Terdeteksinya bakteri $M$. tuberculosis dengan menggunakan metode LAMP-TB karena prinsip kerjanya yang bekerja secara spesifik dalam hal uji molekuler yang dapat mendeteksi DNA bakteri. ${ }^{5}$ Selain itu keunggulan metode LAMP-TB ialah memiliki sensitivitas, spesifitas, dan efisiensi yang tinggi serta merupakan metode paling sederhana dalam hal uji molekuler dan hanya memerlukan sampel yang tergolong sedikit yaitu $60 \mu \mathrm{l}$ sputum untuk dapat mendeteksi TB. ${ }^{28,29}$

\section{SIMPULAN}

Berdasarkan hasil penelitian ini dapat disimpulkan bahwa teknik LAMP-TB dapat mendeteksi $M$. tuberculosis pada sampel sputum BTA negatif.

\section{SARAN}

Perlu dilakukan pembahasan dan penelitian lebih lanjut tentang teknik pemeriksaan Loop-Mediated Isothermal Amplification (LAMP-TB) sebagai alat diagnostik penyakit TB di masa depan, terutama bagi kasus dengan pemeriksaan fisik yang tidak didukung oleh metode 
diagnostik standar seperti pemeriksaan basil tahan asam dengan pewarnaan Ziehl Neelsen, sedangkan terapi yang adekuat perlu segera diberikan dan untuk mengurangi risiko penularan penyakit.

Perlu dilakukan follow-up dan observasi pada pengidap dengan hasil BTA negatif dengan LAMP-TB yang positif. Demikian pula pada pengidap dengan hasil LAMP-TB negatif perlu diobservasi lebih lanjut.

\section{DAFTAR PUSTAKA}

1. Amin Z, Bahar A.Tuberculosis Paru. In: Setiati S, Alwi I, Suudoyo AW, Simadibrata MK, Setiyohadi B, Syam AF, editors. Ilmu Penyakit Dalam Jilid I (6th ed). Jakarta: InternaPublishing, 2014; p. 863-71.

2. World Health Organization. Global Tuberculosis Report. Switzerland: WHO, 2016.

3. Kementerian Kesehatan RI. Data dan Informasi: Profil Kesehatan Indonesia. Jakarta: Kemenkes RI, 2017.

4. Balitbang Kemenkes RI. Riset Kesehatan Dasar. Jakarta: Balitbang Kemenkes RI. 2013.

5. Kementerian Kesehatan RI. Pedoman Operasional Baku Uji Diagnostik Molekular Loop Mediated Isothermal Amplification (LAMP) untuk Deteksi Cepat TB paru di Indonesia. Jakarta: Kemenkes RI, 2012.

6. Alsagaff H, Mukty HA. Dasar-Dasar Ilmu Penyakit Paru. Surabaya: Airlangga University Press, 2009; p. 73-108.

7. Boehme CC, Nabeta P, Henostroza G, Raqib R, Rahim Z, Gerhard M, et al. Operational feasibility of using loopmediated isothermal amplification for diagnosis of pulmonary tuberculosis in microscopy centers of developing countries. J Clin Microbiol. 2007;45: 1936-40

8. Nester EW, Anderson DG, Roberts JCE. Microbiology: A Human Perspective (5th ed). New York: Mc Graw Hill, 2007; p. 245-63.

9. Gantz NM, Brown RB, Berk SL, Myers JW. Manual of Clinical Problems in Infectious Disease: Role of Tuberculin Test (5th ed). Philadelphia: Lippincott Williams \& Wilkins, 2006; p. 407-11.
10. Achkar JM, Jenny-Avital E, Yu X, Burger S, Leibert E, Bilder PW, et al. Antibodies against immunodominant antigens of mycobacterium tuberculosis in subjects with suspected tuberculosis in the United States Compared by HIV Status. Clin Vaccine Immunol. 2010;17(3):384-92.

11. Saharan P, Dhingolia S, Khatri P, Duhan JS, Gahiawat SK. Loop-mediated isothermal amplification (LAMP) based detection of bacteria: a review. Afr J Biotechnol. 2014;13(19):1920-8.

12. Kemenkes RI. Petunjuk Pelaksanaan pemeriksaan TB menggunakan alat Genexpert. Jakarta: Kemenkes RI, 2015; p. 2-9.

13. Notomi T, Okayama H, Masubuchi $H$, Yonekawa T, Watanabe $\mathrm{K}$, Amino $\mathbf{N}$, et al. Loop-mediated Isothermal Amplification of DNA. Nuclei Acids Res. 2000;28(12):E63.

14. Mori Y, Nagamine K, Tomita N, Notomi T. Detection of loop-mediated isothermal amplification reaction by turbidity derived from magnesium pyrophosphate formation. Biochem Biophys Res Commun. 2001;23:150-4.

15. Enosawa M, Kageyama $S$, Sawai $K$, et al. Use of loop-mediated isothermal amplification of the IS900 sequence for rapid detection of cultured Mycobacterium avium subsp. Paratuberculosis. J Clin Microbiol. 2003;41: 4359-65.

16. Drapala D, Kordalewska M. LoopMediated Isothermal Amplification (LAMP) as a Diagnoistic tool in detection of infectious diseases. PhD Interdisciplinary Journal. 2011;12:1923.

17. Iwamoto T, Sonobe T, Hayashi K. Loopmediated isothermal amplification for direct $\mathrm{d}$ etection of mycobacterium tuberculosis comples, m. Avium, and $\mathrm{m}$. Intracellulare in sputum samples. JI Clin Microbiol. 2003;41(6):2616-22.

18. Kaku T, Minamoto F, Meza RD, Morose $\mathrm{W}$, Boney $\mathrm{J}$, Bijou $\mathrm{J}$, et al. Assessment of accuracy of LAMP-TB method for diagnosing tuberculosis in Haiti. Jpn J Infect Dis. 2016;519:1-17.

19. World Health Organization. The use of Loopmediated Isothermal Amplification (TB-LAMP) for the diagnosis of 
pulmonary tuberculosis. Geneva: WHO, 2016. h. 1-38.

20. Senarath KD, Usgodaarachchi RB, Navaratne $V$, Nagahawatte A, Wijayarathna CD, Alvitigala J, et al. Non specific amplification with the LAMP technique in the diagnosis of tuberculosis in Sri Lankan settings. J Tuberc Res. 2014;2:168-72.

21. Putra IWA, Surjanto E, Aditama TY. Nilai diagnostic pemeriksaan rantai polymerase pada tuberculosis paru sputum basil tahan asam negatif. J Respir Indo. 2008;28(3):136-43.

22. Kurniawan E, Raveinal, Fauzar, Arsyad Z. Nilai diagnostik metode "Real Time" PCR geneXpert pada TB Paru BTA negatif. Jurnal Kesehatan Andalas. 2016;5(3):730-7.

23. Setiarsih HS, Wiyono WH, Burhan E, Soemanto RK, Widyahening IS. Sensitivitas dan spesifitas kultur Mycobacteria Tuberculosis menggunakan media cair pada sediaan Bronchoalveolar Lavage (BAL) dari pasien tuberculosis paru BTA negatif. J Respir Indo;32(2):89-98.

24. World Health Organization. Tuberculosis : A Manual for Medical Students. Geneva:WHO, 2005; p. 84-5.

25. Centers for Disease Control and Prevention.
Chapter 2: Transmission and Pathogenesis of Tuberculosis. 2016 March 20 [cited 2017 Sep 9]. Available from: http://www.cdc,gov/tb/education/corec urr/pdf/chapter2.pdf

26. Andina M, Amir Z, Siregar Y. Deteksi Mycobacterium tuberculosis pada sputum penderita tuberculosis paru basil tahan asam negatif dengan reaksi rantai polimerase. 2012 Juli 12 [cited 2017 November 8]. Available from: http://repository.usu.ac.id/handle/12345 $6789 / 33327$

27. Mitarai S, Okumura M, Toyota E, Yoshiyama T, Aono A, Sejimo A, et al. Evaluation of a simple loopmediated isothermal amplification test kit for the diagnosis of tuberculosis. Int J Tuberc Lung Dis. 2011;15(9):1211-6.

28. Gray CM, Katamba A, Narang P, Giraldo J, Zamudio C, Joloba M, et al. Feasibility and operational performance of tuberculosis detection by loopmediated isothermal amplification platform in decentralized settings: Results from a Multicenter Study. J Clin Microbiol. 2016;54(8):1984-90.

29. Sastroasmoro S, Ismael S. Dasar-dasar Metodologi Penelitian Klinis (5th ed). Jakarta: Sagung Seto, 2014. 